\title{
Creative-Thinking Skills in Explanatory Writing Skills Viewed from Learning Behaviour: A Mixed Method Case Study
}

\author{
https://doi.org/10.3991/ijet.v15i01.11487 \\ Bening Sri Palupi $\left.{ }^{\bowtie}\right)$, Slamet Subiyantoro, \\ Triyanto, Rukayah \\ Universitas Sebelas Maret, Surakarta, Indonesia \\ beningsip@student.uns.ac.id
}

\begin{abstract}
Creative thinking involves the activities of complex skills and cognitive abilities, personality factors and motivations, styles, strategies, and metacognitive skills. Therefore, creative-thinking skills can reflect the students' personality considered as unique individuals. On the other hand, the effectiveness of education can be seen from teaching practices and class climate. The application of guided inquiry learning (GIL) and problem-based learning (PBL) models is one effort to improve the effectiveness of education. This research is a mixed-method case study that aims to describe the behaviour of groups of students, studying with GIL and PBL, with high, moderate, and low creativethinking skills. The mixed-method analysis applied is a concurrent embedded strategy that combines primary data (qualitative) and secondary data (quantitative) to complement each other. The results showed that the application of the GIL and PBL models was proved to be effective for learning explanatory writing skills. In terms of the creative-thinking skills, the higher the students' creative-thinking skills are, the higher their explanatory writing skills will be. Students who have high creative-thinking skills also exhibit prominent attitudes during the learning process, such as intensity of asking frequently with substantive questions on the subject matter and having good opinion and leadership skills.
\end{abstract}

Keywords - Creative thinking skills, guided inquiry learning, problem-based learning, writing skills.

\section{Introduction}

The education world is inseparable from the learning model applied in the classroom. This is also a major factor in determining the success of educational goals. Educational innovation starts from a class before finally being applied to a wider scale. However, educational innovation is also a challenge for educators because they must address the needs of different students in a class. PISA 2018 suggests that the main challenge of PISA concerns measuring and documenting educational outcomes that have been achieved until the age of 15 years. Basically, educating someone 
means encouraging his personal development as a unique, self-determined, and knowledgeable person who gradually gains the ability to participate in society $[1, \mathrm{p}$. 99]. Therefore, educational innovations carried out must look in terms of student characteristics and academic needs. Academic needs can be done by implementing innovative learning models. The students' characteristics can be done by paying attention to their thinking abilities. PISA also reveals that the effectiveness of education can be identified from teacher qualifications, teaching practices, class climate, study time and learning opportunities provided both inside and outside of school [1, p. 100].

As explained above, one of the effectiveness of education is teaching practice. This clarifies that it is urgent that innovative learning models be applied as an effort to improve the quality of education. In the same case, PISA reveals that the teaching process must also be focused on three dimensions, namely class structure and management, teacher support, and cognitive challenges. PISA also views students as individuals who are unique in the social sphere [1, p. 101]. Therefore, we conduct research by implementing innovative learning models. The innovative learning model chosen is the guided inquiry learning model (GIL) and problem-based learning (PBL). We chose this model based on the consideration that both are based on problem solving [2]-[5] so that it is relevant to the global demands of education. In addition, we also focus on students' thinking skills as their personal development that is unique and can be determined by themselves. The type of thinking we choose is the creativethinking skill. Today's disruptive technology requires the ability to think creatively to produce solutions that are useful in certain situations [6].

Creative thinking involves the activities of complex skills and cognitive abilities, personality factors and motivations, styles, strategies, and metacognitive skills [7]. Therefore, creative-thinking skills can reflect the students' personality considered as unique individuals. Combining learning model and creative-thinking skill variables in one research is expected to be a substantial contribution to the world of education. However, we focus on how students' creative thinking skills play in a series of learning processes with innovative models. Creativity means a creation. All that is done by someone who produces a product is interpreted very broadly so that it includes not only physical objects but also mental states and structures (thoughts), circumstances, events and actions, and creative products themselves as well as the creator himself [8]. In this research, both innovative learning models (GIL and PBL) were applied to improve explanatory writing skills. Thus, explanatory text becomes the students' product at the end of learning which is seen as the result of their creativity in conveying information. The topics that we applied in research are the human respiratory system and its disorders. Students explained this into explanatory texts including providing solutions on how to deal with the disruption of the human system.

The creative-thinking process refers to the sequence of cognitive activities that can lead to something new, but according to work in the context of the problem given [9]. Before applying the innovative learning model, we tested the students' creativethinking to classify high, medium, and low levels of creative-thinking skills. After that, we focused on student attitudes when learning took place to analyse individual differences in high, medium and low creative-thinking skills. This corresponds with the opinion of Wechsler, Vendramini, and Oakland [10] that understanding of creativ- 
ity is enhanced through an assessment of individual differences that are described by the style that is the preferred way of thinking and behaving. This kind of research is still rare. The previous research examined more about the assessment of creative thinking skills [10]-[13] and focused on improving and developing them [14]-[19]. Besides, creative thinking can be defined as a whole set of cognitive activities used by individuals in accordance with certain objects, problems and conditions, or types of efforts towards certain events and problems based on individual capacity [20]. Cognitive activities can be seen during the learning process. Therefore, we focus on behaviours that arise in children with high, medium and low creative-thinking skills.

\section{$2 \quad$ Method}

\subsection{Participant}

Participants in this study were fifth-grade primary school students in Surakarta, Central Java, Indonesia. The participants included 162 fifth-grade students selected through a multi-stage sampling [21] that were divided into two groups, consisting of 81 students for the GIL group and 81 students for the PBL group.

\subsection{Material}

The materials in this research consisted of qualitative and quantitative data. The qualitative data in the form of observations and interviews were used as primary data sources, while the quantitative data consist of test scores of creative-thinking skills and explanatory writing skills used as secondary methods and embedded into the primary method to support each other and strengthen the research results.

The quantitative method used quasi experiment with $2 \times 3$ factorial design, while qualitative methods used case study. The quasi experiment involves humans as the subjects whose focus of study and measurement generally lies in the aspects of their behaviours which were systematically manipulated without regard to the obstacles encountered in conducting the research [22]. Case study is an empirical investigation of phenomena that occur at the same time in depth and in real life contexts, especially when the boundaries between phenomena and contexts are unclear. In other words, the case study is used when a researcher wants to understand real-life phenomena in depth which includes important contextual conditions [23].

After obtaining qualitative data (primary) and quantitative data secondary), they were compared to complement each other. This analysis of mixed-method data is called concurrent embedded strategy. The concurrent embedded strategy has primary methods that guide projects and secondary databases that play a supporting role in research procedures [24]. Secondary methods that are less prioritized (quantitative or qualitative) are embedded or nested into more dominant methods (quantitative or qualitative). 


\section{$3 \quad$ Result}

\subsection{Stage 1 (Pretest-quantitative data)}

The results of descriptive statistics for the creative-thinking skills and the pretest of explanatory writing skills are presented in Table 1.

Table 1. Test results of creative-thinking skills and pretest of explanatory writing skills

\begin{tabular}{|l|c|c|c|c|}
\hline $\begin{array}{c}\text { Level of Creative- } \\
\text { Thinking Skills }\end{array}$ & $\begin{array}{c}\text { GIL } \\
\text { Group }\end{array}$ & $\begin{array}{c}\text { Mean of Pretest Explana- } \\
\text { tory Writing Skill }\end{array}$ & $\begin{array}{c}\text { PBL } \\
\text { Group }\end{array}$ & $\begin{array}{c}\text { Mean of Pretest Explanatory } \\
\text { Writing Skill }\end{array}$ \\
\hline High & 27 & 61 & 24 & 55 \\
\hline Medium & 25 & 55 & 35 & 50 \\
\hline Low & 29 & 41 & 22 & 52 \\
\hline Number of Students & 81 & - & 81 & - \\
\hline
\end{tabular}

\subsection{Stage 2 (Qualitative data and posttest-quantitative data)}

Qualitative data were collected from observations during learning. We also interviewed the teacher after the posttest. The qualitative data were in the form of how creative-thinking skills play a role in the learning process. Posttest was conducted to find out more about whether there were differences in explanatory writing skills before and after applying the GIL and PBL models. We also put forward a hypothesis to analyse quantitative data.

- H01: There is no difference in explanatory writing skills of students in the high, medium and low creative-thinking groups

- H02: There is no interaction between learning models and creative-thinking skills for explanatory writing skills

The observations showed that the behaviour at each level of creative-thinking skills, both in the GIL and PBL groups, exhibit similarities when learning took place. The groups of students who have high creative-thinking skills exhibit the following behaviours: often asking questions to the teacher, often giving feedback/opinions, and having a good leadership. The groups of students with medium creative-thinking skills also exhibit questioning and responding skills during learning but the questions asked are less qualified in terms of the material. On one hand, the groups of students with low creative-thinking skills tend to follow the direction of group friends, they do not dare to ask and respond to the teacher. They only asked questions and responded to learning through their group friends. The teacher also recognizes that the students with high creative-thinking skills exhibit these behaviours in everyday learning.

The quantitative data were analysed using two-way Anava. The results are presented in Table 2 below. 
Table 2. Sumarry of two-way anava test

\begin{tabular}{|l|c|c|c|c|c|l|}
\hline \multicolumn{1}{|c|}{ Source } & Gender & Dk & RK & Fobs & Ftable & Test Decision \\
\hline Learning Model (A) & 2228 & 1 & 2228 & 31 & 3.9 & H0 rejected \\
\hline Creative-Thinking Skills (B) & 12506 & 2 & 6253 & 86.5 & 3.05 & H0 rejected \\
\hline Interaction & 86 & 2 & 43 & 0.6 & 3.05 & H0 accepted \\
\hline Error & 11274 & 156 & 72 & - & - & - \\
\hline Total & 26094 & 161 & - & - & - & - \\
\hline
\end{tabular}

Based on Table 2 above, the following results can be obtained:

The main effect of the column, the significance level of students' creative-thinking skills (B) is $5 \%$ with Fobs test score $=86.5, \mathrm{~F}(0.05 ; 1 ; 156)=3.05$ and the critical area for creative thinking skills $\mathrm{DKb}=\{\mathrm{F} \mid \mathrm{F}>3.05\}$. Thus, H0B is rejected. This means that among students who have high, moderate, and low creative-thinking skills, they have different explanatory writing skills.

On the main effect of the interaction, namely the interaction between learning models and creative thinking skills, the significance level is $5 \%$ with Fobs test score $=$ $0.6, \mathrm{~F}(0.05 ; 1 ; 156)=3.05$ and the critical area for creative-thinking skills $\mathrm{DKb}=\{\mathrm{F} \mid$ $\mathrm{F}>3.05\}$. Thus, H0B is accepted. This means there is no interaction between the learning model and creative-thinking skill.

Based on the calculation of two-way Anava of the different cells above, there is no interaction between the learning model and creative-thinking skill. Therefore, the advanced post-Anava test was not necessarily to be done. The comparison of the mean between cells refers to the following marginal mean ratio:

Table 3. Posttest results of explanatory writing skills

\begin{tabular}{|l|c|c|c|c|}
\hline \multirow{2}{*}{ Learning Model } & \multicolumn{3}{|c|}{ Creative-Thinking Skills } & \multirow{2}{*}{ Marginal Mean } \\
\cline { 2 - 4 } & High & Medium & Low & 71 \\
\hline GIL & 81 & 72 & 61 & 64 \\
\hline PBL & 75.5 & 64 & 52 & \\
\hline Marginal Mean & 78.25 & 68 & 56.5 & \\
\hline
\end{tabular}

Table 3 shows that the higher the creative-thinking skills are, the higher the explanatory writing skills will be.

\section{Discussion}

The results showed that the GIL and PBL models were effective for improving students' explanatory writing skills. This can be seen in the pretest and posttest scores. Based on the calculation of two-way Anava of different cells before, it is concluded that there were differences in explanatory writing skills of the students who have high, medium, and low creative thinking skills. Judging from the marginal mean (see table 3 ), it shows that in the GIL and PBL student groups, the explanatory writing skills of the students who have high levels of creative thinking are better than those who have moderate creative-thinking skills. Then, explanatory writing skills of the students who 
have moderate creative-thinking skills are better than those who have low creativethinking skills.

\subsection{Questioning skill}

The groups of students with high creative-thinking skills often ask questions. This is related to solving problems that they will do. This is as said by Deren and Skonieczny [6] that one element of creative thinking is innovative thinking, while innovative thinking shows the behaviour of frequently asking. Innovators seek solutions by asking questions that will help them understand how things are seen so they can be changed and improved. The questions asked will lead to new observations, relationships, opportunities, and lines of action. The intensity of this question is also influenced by elements inherent in cognitive skills, namely recursion/repetition, representation, and curiosity [25]. Therefore, creative output can arise from various activities. Cognitive skills as the basis of design thinking that conceptually give us the mental ability to produce a structure of knowledge of an object, environment, or situation. Regarding the element of cognitive skills, the recursion meant by Dong allows us to combine things into new mental scenarios [25]. Meanwhile, representation allows us to interpret and evaluate understanding that allows us to consider various solutions. Furthermore, curiosity makes us compelled to find out. The intensity of sufficient questioning for students who have high creative-thinking skills makes them combine new knowledge to make them produce explanatory writing skills that are better than the groups of students who have moderate and low creative-thinking skills.

The description above can give us an understanding that the higher one's creativethinking skill is, the higher his intensity of action to find out will be. This questioning skill will help students solve problems. Therefore, creativity plays an important role in solving everyday problems [19]. Creative thinking also has a synthesis dimension that includes various activities such as getting original results from small parts, presenting new and authentic suggestions for solutions to a problem [20]. Frequently asked questions by the groups of students who have high creative-thinking skills indicate that they have not found an answer to the problem given when synthesizing various prior knowledge. Therefore, they integrate previous learning to get new information by actively participating in class activities [26].

On the one hand, to achieve authentic science inquiry in the classroom, the teacher must implement cognitive questioning teaching questions. Therefore, the teacher must engage in less demanding cognitive questions to reduce the cognitive load of students [27]. Both teachers who apply GIL and PBL, both create a dialogical classroom atmosphere. Through the question and answer process, students face each other about conflicting views, generating question and answer sessions, to refute, acknowledge or justify their ideas to reach new arguments [28]. However, for groups of students who have high creative thinking skills, teachers do not need to try hard to lure students to ask questions. Individual differences in creativity do arise in cognitive processes [19]. However, that does not mean the teacher does not need to liven up the atmosphere in the classroom by asking questions. Teachers remain in their role of facilitators of learning because creativity is a process of thinking and acting [29], where groups of 
students who have moderate and low creativity can also develop their questioning skills during the learning process. Although the lower the ability of creative thinking students the lower the quality of questioning skills. Knowledge-based questions can be used to confirm students' understanding of the material they are learning [30]. The difference in learning behaviour shown by groups of students with high, medium and low creative thinking skills is not the effect of the applied learning model (GIL and PBL). Creativity is not a physical act, creativity is more technical reasoning than abstract reasoning [31]. Educational practice produced by creative thinking has a significant impact on students' creative scientific thinking and cognitive process skills [26].

\subsection{Opinion skills}

The groups of students who have high creative-thinking skills exhibit the same behaviour, both in the GIL and PBL groups, which often provide responses or opinions during the learning process. The opinions expressed are qualified because they are related to the essential elements related to the topic. Meanwhile, the groups of students who have moderate creative-thinking skills also dare to give opinions even though the intensity is less. Although there was a time for them to an opinion with the same intensity as the groups of students who have high creative-thinking skills, the opinions given did not touch the essence of the topic. For example, when the teacher gave a short story about human respiratory in which there are several characters in the story, then the teacher asked, "Why are there characters who cough up?" The students who have high creative-thinking skills could give an opinion that polluted air causes us to cough because inhaled oxygen mixes with the exhaust gases of motor vehicles. Meanwhile, when we are under a shady tree, we will feel fresh air because the tree releases photosynthetic oxygen needed for our respiratory.

Different from the groups of students who have moderate creative-thinking skills, their opinions are shorter; for example, they only explained that respiratory can be disrupted because of dirty air due to many motor vehicles. Their opinions also still explain the events in the story; for example, the characters in the story cough when they go home from school because they are walking on the outskirts of the city which are often crossed by motor vehicles. Furthermore, for groups of students who have low creative-thinking skills tend not to dare to give opinions during the learning process. Even if the teacher gave a question, their answer was only yes or no.

Opinion skills shown by the groups of students with high creative-thinking skills indicate that they listen to the teacher well so that they can provide opinions that touch the essence of the topic, namely human respiratory. It is as found by Aldig and Arseven [16] that listening is one of the four basic language skills that can encourage students to think creatively. The listening results can help them think in a multidimensional manner and avoid learning to memorize. Opinions expressed by the groups of students with high creative-thinking skills are not the results of their memorization before, but the results of problem investigation from various reading sources around them. Baum and Newbill [32] revealed that one element of creative thinking is an attitude of confidence that they are confident in their ability to solve problems. This belief includes showing courage in giving judgement and taking risks. Regarding 
speaking skills, Szymańska-Czaplak [33] found that students realize that they can talk when they are ready, without feeling stressed about the answers that will be given immediately.

Regarding the use of the GIL and PBL models, although the intensity of students' speaking at each level of creative thinking ability is different, both models can support speaking skills during the learning process because the problems given are a matter of daily life that is close to their environment. This is as found by Zahoor-Ul-Haq, Khurram, and Bangash [34] that the selection of appropriate teaching methods can improve speaking skills and confidence in speaking. The ability to speak science can also be seen from previous scientific knowledge and language skills [35]. However, that does not mean that the two models (GIL and PBL) can improve explanatory writing skills. The ability to think creatively is an integral part of cognitive readiness. Individuals, when studying alone or in school or when working alone or in a team environment, can utilize their knowledge, skills and competencies related to, for example, problemsolving and decision making [18, p. 202].

Explanation texts produced by students also increase along with the level of creative thinking abilities. Questioning and opinion skills are increasingly shown along with the level of creative thinking ability to make students able to synthesize information. It is this synthesis of information that makes them able to design the outline. Creative thinking involves complex cognitive activity and cognitive abilities, personality and motivation factors, style, strategy, and metacognition skills [7]. Therefore, creative thinking is also defined as a process that cannot be separated from cognitive abilities. Individual cognitive abilities produce knowledge and meaning through sequential development such as mental processes of recognizing, remembering, analyzing, reflecting, applying, making, understanding, and evaluating [36]. These cognitive activities and abilities produce good explanatory text quality.

\subsection{Leadership skills}

Students who have high creative-thinking skills have good leadership in the classroom. This is indicated by the class leader of the six schools at the level of high creative-thinking skill obtaining the score of explanatory writing skills above the average score of all students. This shows that one characteristic of someone who has high creative-thinking skill is having good leadership. In addition, good leadership in students who have high creative-thinking skills is also shown during the learning process in the classroom. Even though they are not class leaders, they can direct their groups to be active in problem solving by leading the division of group tasks when looking for information.

In connection with good leadership in groups of students with high creativethinking skills, Coffey and Lavery [37] reveals that students can participate in discussions or other collaborative activities to build their leadership attitude. Hine [38] found that students who have good leadership have the willingness to help and encourage others to work. Based on the research results, both the GIL and PBL models used problems as learning frameworks with discussion activities. Implementing such collaborative activities can greatly help classroom teachers grow student leadership 
skills such as strategy design, problem solving, and decision making [39]. In addition, leadership also has a positive relationship to academic optimism [40]. The groups of students with high creative-thinking skills exhibit optimism when giving opinions and asking questions.

As part of cognitive readiness, creative thinking is seen as a disposition, as is openness to new ideas [18, p. 202]. This attitude of openness is utilized by students who have high creative thinking skills to generate new ideas in finding solutions. Those who have high creative thinking skills are quick-minded, have leadership qualities and are always valued by people around them [16]. Creative attitudes come from what is inside the individual but can be intentionally influenced and directed by the individual climate. Creative attitudes enable individuals to digest raw materials that nourish creative thinking, such as information, knowledge, skills, emotions, and experience, and also function as a pathway to creative ideas [41].

Guilford said creativity has main characteristics namely sensitivity to problems, the ability to produce ideas, flexibility and novelty of ideas, and the ability to synthesize and reorganize information [42]. This arises in the learning behaviour of students who have high creative thinking abilities. Leadership attitudes that emerge indicate that students who have high creative thinking ability have the sensitivity to learning tasks. The ability to think creatively is a representation of mental habits and methods for solving problems [43]. Creativity consists of abilities and personality [44] which can be understood by individual differences in thinking and behaving [10]. Although not all students who have high creative thinking skills become group leaders. They show their fluency in discussions, such as sharing and exchanging information [42].

\section{Conclusion}

Based on the research conducted, students who have high creative-thinking skills exhibit prominent attitudes during the learning process, such as intensity of asking frequently with substantive questions on subject matter and having good opinion and leadership skills. Apart from differences in behaviour in the groups of students with high, medium, and low creative-thinking skills. The application of the GIL and PBL models has been proved effective for learning explanatory writing skills. Plus, the topic of the human respiratory system and its disorders makes students learn how to protect the environment. The GIL and PBL models also develop their collaborative skills. It is as stated by PISA 2018 that effective education for global competencies gives students the opportunity to mobilize and use their knowledge, skills, attitudes and values together while exchanging ideas about global problems inside or outside of school or when interacting with people from different cultural backgrounds [45, $\mathrm{p}$. 169]. The writing produced by students also shows how students think skills [46]. Therefore, differences in attitudes exhibited by groups of students with high, medium, and low creative-thinking skills can be considered by the teacher in providing treatment during learning. Teachers must be able to create a good classroom and collaborative atmosphere to improve students' writing skills [47], [48]. 


\section{References}

[1] OECD, "PISA 2018 Draft Analitycal Frameworoks May 2016," 2018.

[2] D. Sokołowska, "Effectiveness of Learning Through Guided Inquiry," in The Role of Laboratory Work in Improving Physics Teaching and Learning, M. M. Sokołowska D., Ed. Cham: Springer, 2018, pp. 243-255. https://doi.org/10.1007/978-3-319-96184-2 20

[3] S. De Gale and L. N. Boisselle, "The Effect of POGIL on Academic Performance and Academic Confidence,” Sci. Educ. Int., vol. 26, pp. 56-79, 2015.

[4] W. Hung, "All PBL Starts Here: The Problem," Interdiscip. J. Probl. Learn., vol. 10, no. 2, 2016. https://doi.org/10.7771/1541-5015.1604

[5] F. Adamidi, F. Paraskeva, H. Bouta, and S. Gkemisi, "Problem-based learning in language instruction: A collaboration and language learning skills framework in a CSCL environment," in Learning Technology for Education Challenges. LTEC 2017. Communications in Computer and Information Science, L. Y. Uden L., Liberona D., Ed. Cham: Springer, 2017, pp. 133-146. https://doi.org/10.1007/978-3-319-62743-4 12

[6] A. M. Dereń and J. Skonieczny, "Creative Thinking in Management of Disruptive Technologies Creative thinking," in Information Systems Architecture and Technology: Proceedings of 37th International Conference on Information Systems Architecture and Technology - ISAT 2016 - Part IV, 2017, pp. 189-196. https://doi.org/10.1007/978-3-319$\underline{46592-0 \quad 16}$

[7] N. Leggett, "Early Childhood Creativity: Challenging Educators in Their Role to Intentionally Develop Creative Thinking in Children," Early Child. Educ. J., vol. 45, no. 6, pp. 845-853, 2017. https://doi.org/10.1007/s10643-016-0836-4

[8] M. Wreen, “Creativity," Philosophia (Mendoza)., vol. 43, pp. 891-913, 2015. https://doi.org/10.1007/s11406-015-9607-5

[9] L. Zeng, R. W. Proctor, and G. Salvendy, "Can Traditional Divergent Thinking Tests be Trusted in Measuring and Predicting Real-World Creativity?," Creat. Res. J., vol. 23, no. 1, pp. 24-37, 2011. https://doi.org/10.1080/10400419.2011.545713

[10] S. M. Wechsler, C. M. M. Vendramini, and T. Oakland, "Thinking and Creative Styles: A Validity Study," Creat. Res. J., vol. 24, no. 2-3, pp. 235-242, 2012. https://doi.org/10.1080/10400419.2012.677359

[11] I. Gusti, A. Tri Agustiana, and R. Agustini, "The Prototype Development of Creative Thinking Skills Model'S Book," in Global Conference on Teaching, Assessment, and Learning in Education (GC-TALE 2017), 2018, vol. 42. https://doi.org/10.1051/ $\underline{\text { shsconf } / 20184200116}$

[12] S. Sehic, "The Effect of English Language Learning on Creative Thinking Skills : A Mixed Methods Case Study," English Lang. Teach., vol. 10, no. 3, pp. 82-94, 2017. https://doi.org/10.5539/elt.v10n3p82

[13] G. Hawthorne et al., "Designing a Creativity Assessment Tool for the Twenty-First Century: Preliminary Results and Insights from Developing a Design-Thinking Based Assessment of Creative Capacity," in Design Thinking Research. Understanding Innovation, L. L. Plattner H., Meinel C., Ed. Cham: Springer, 2016, pp. 111-123. https://doi.org/10.1007/978-3-319-19641-1 8

[14] N. L. Rábanos and P. A. Torres, "Effects of A Program for Developing Creative Thinking Skills," Educ. Psychol., vol. 10, no. 2, pp. 1139-1158, 2012.

[15] S. Winarno, K. S. Muthu, and L. S. Ling, "Direct Problem-Based Learning ( DPBL ): A Framework for Integrating Direct Instruction and Problem-Based Learning Approach," Int. Educ. Stud., vol. 11, no. 1, pp. 119-126, 2018. https://doi.org/10.5539/ies.v11n1p119 
[16] E. Aldig and A. Arseven, "The Contribution of Learning Outcomes for Listening to Creative Thinking Skills," J. Educ. Learn., vol. 6, no. 3, pp. 41-53, 2017. https://doi.org/10.5539/jel.v6n3p41

[17] S. R. Tandiseru, "The Effectiveness of Local Culture-Based Mathematical Heuristic-KR Learning towards Enhancing Student's Creative Thinking Skill," J. Educ. Pract., vol. 6, no. 12, pp. 74-82, 2015.

[18] E. Hong, "Creative Thinking Abilities: Measures for Various Domains," in Teaching and Measuring Cognitive Readiness, B. E. O’Neil H., Perez R., Ed. Boston, MA: Springer, 2014, pp. 201-222. https://doi.org/10.1007/978-1-4614-7579-8 11

[19] S. M. Ritter and N. Mostert, "Enhancement of Creative Thinking Skills Using a CognitiveBased Creativity Training," J. Cogn. Enhanc., vol. 1, no. 3, pp. 243-253, 2017. https://doi.org/10.1007/s41465-016-0002-3

[20] B. Birgili, "Creative and Critical Thinking Skills in Problem-based Learning Environments," J. Gift. Educ. Creat., vol. 2, no. 2, pp. 71-80, 2015.

[21] J. W. Cresswell, Research Design: Qualitative, Quantitative, and Mixed Methods Approaches Fourth Edition. United States of America: Sage Publications, 2014.

[22] M. Ali and M. Asrori, Metodologi dan Aplikasi Riset Pendidikan. Jakarta: Bumi Aksara, 2014.

[23] R. K. Yin, Case Study Research Design and Methods Fourth Edition. United States of America: Sage Publications, 2009.

[24] J. W. Cresswell, Research Design Pendekatan Kualitatif, Kuantitatif, dan Mixed. Yogyakarta: Pustaka Pelajar, 2017.

[25] A. Dong, "Design Thinking as Principles for the Structure of Creative Cities," in Complexity, Cognition, Urban Planning and Design. Springer Proceedings in Complexity, 2016, pp. 93-107. https://doi.org/10.1007/978-3-319-32653-5 6

[26] S. D. Kaçan, "A Situatıonal Study for the Identificatıon of Pre-Service Science Teachers ' Creatıve Thinking and Creatıve Scientıfic Thinkıng Skills," J. Educ. Pract., vol. 6, no. 27, pp. 82-86, 2015.

[27] Y. Soysal, "Investigating Discursive Functions and Potential Cognitive Demands of Teacher Questioning in The Science Classroom," Learn. Res. Pract., pp. 1-28, 2019. https://doi.org/10.1080/23735082.2019.1575458

[28] M. J. (Zé) Loureiro, F. N. de Souza, A. Bezerra, and A. Rodrigues, "Collaboration, Knowledge Sharing and Digital Environments: What about Argumentation and Questioning Skills?," in Learning and Collaboration Technologies. Technology-Rich Environments for Learning and Collaboration. LCT 2014. Lecture Notes in Computer Science, vol 8524, 2014, pp. 440-449. https://doi.org/10.1007/978-3-319-07485-6 43

[29] T. Bhatnagar and P. Badke-schaub, "Design Thinking and Creative Problem Solving for Undergraduate Engineering Education in India: The Need and Relevance," in Research into Design for Communities, Volume 2. ICoRD 2017. Smart Innovation, Systems and Technologies, vol 66., 2017, pp. 953-967. https://doi.org/10.1007/978-981-10-3521-0_81

[30] Milawati and N. Suryati, "EFL Teacher's Oral Questioning: Are Her Questions and Strategies Effective?," Din. Ilmu, vol. 19, no. 1, pp. 37-55, 2019. https://doi.org/10.21093/di.v19i1.1545

[31] C. Baber, "Thinking with Hands, Acting with Minds: Embodied Cognition and Creative Practice," in Proceedings of the 20th Congress of the International Ergonomics Association (IEA 2018). IEA 2018. Advances in Intelligent Systems and Computing, vol 824, 2019, pp. 225-234. https://doi.org/10.1007/978-3-319-96071-5 24 
[32] B. L. M. Baum and P. L. Newbill, "Instructional Design as Critical and Creative Thinking: A Journey Through a Native American Village," Tech Trends, vol. 54, no. 5, pp. 27-37, 2010. https://doi.org/10.1007/s11528-010-0434-z

[33] E. Szymańska-Czaplak, "Developing and Testing Speaking Skills in Academic Discourse," in Issues in Teaching, Learning and Testing Speaking in a Second Language. Second Language Learning and Teaching, Berlin: Springer, 2015, pp. 233-250. https://doi.org/10.1007/978-3-642-38339-7_15

[34] Zahoor-Ul-Haq, B. A. Khurram, and A. K. Bangash, "Development of Speaking Skills through Activity Based Learning at the Elementary Level," Eurasian J. Educ. Res., vol. 69, pp. 241-252, 2017. https://doi.org/10.14689/ejer.2017.69.13

[35] S. Lin, Y. Liu, S. Chen, J. Wang, and H. Kao, "Elementary School Students ' Science Talk Ability in Inquiry-Oriented Settings in Taiwan: Test Development, Verification, and Performance Benchmarks," Int. J. Sci. Math. Educ., vol. 14, no. 7, pp. 1199-1214, 2016. https://doi.org/10.1007/s10763-015-9663-0

[36] C. Fenglong, "Empirical Study on the Application of CALL in Writing Classroom," Int. J. Emerg. Technol. Learn., vol. 10, no. 1, pp. 74-78, 2015. https://doi.org/10.3991/ ijet.v10i1.4297

[37] A. Coffey and S. Lavery, "Improving Schools Student Leadership in the Middle Years: A Matter of Concern," Improv. Sch., pp. 1-14, 2017. https://doi.org/10.1177/1365480 217732223

[38] G. S. C. Hine, "Student Leadership Development: A Functional Framework," J. Cathol. Educ., vol. 18, no. 1, 2014. https://doi.org/10.15365/joce.1801052014

[39] P. Liu, L. Lili, and X. Yijing, "Leadership of Class Teachers ( Banzhuren ) in Improving Student Learning : Case Studies of Chinese Primary Schools," Front. Educ. China, vol. 13, no. 1, pp. 28-55, 2018. https://doi.org/10.1007/s11516-018-0002-4

[40] J. Malloy and K. Leithwood, "Effects of Distributed Leadership on School Academic Press and Student Achievement," in How School Leaders Contribute to Student Success. Studies in Educational Leadership, P. K. Leithwood K., Sun J., Ed. Cham: Springer, 2017, pp. 6991. https://doi.org/10.1007/978-3-319-50980-8 5

[41] K. H. Kim and Y. Hao, "Creative Climate Tests, Creative Attitudes Tests, and Creative Thinking Skills Tests," in Encyclopedia of Creativity, Invention, Innovation and Entrepreneurship, C. E, Ed. New York: Springer, 2019, pp. 1-7. https://doi.org/10. 1007/978-1-4614-6616-1_19-2

[42] T. Okudo, K. Takadama, and T. Yamaguchi, "Designing the Learning Goal Space for Human Toward Acquiring a Creative Learning Skill," in Human Interface and the Management of Information: Supporting Learning, Decision-Making and Collaboration. HIMI 2017. Lecture Notes in Computer Science, vol 10274, 2017, vol. 1, pp. 62-73. https://doi.org/10.1007/978-3-319-58524-6 6

[43] L. Porter, "Teaching the Creative Process: An Essential and Portable Skill," in Creativity in Theatre. Creativity Theory and Action in Education, vol 2, B. S, Ed. Cham: Springer, 2018, pp. 121-129. https://doi.org/10.1007/978-3-319-78928-6 8

[44] L. Kyunghwa and Y. Hyejin, "Cross-cultural Research on the Creativity of Elementary School Students in Korea and Australia," Univers. J. Educ. Res., vol. 4, no. 11, pp. 26182626, 2016. https://doi.org/10.13189/ujer.2016.041115

[45] OECD, PISA 2018 Assessment and Analytical Framework. Paris: OECD Publishing, 2019.

[46] D. Ramadhanti, A. S. Ghazali, M. Hasanah, and T. Harsiati, "Students' Metacognitive Weaknesses in Academic Writing: A Preliminary Research," Int. J. Emerg. Technol. Learn., vol. 14, no. 11, pp. 41-57, 2019. https://doi.org/10.3991/ijet.v14i11.10213 
[47] T. Sulistyo, N. Mukminatien, B. Y. Cahyono, and A. Saukah, "Enhancing Learners' Writing Performance through Blog-Assisted Language Learning," Int. J. Emerg. Technol. Learn., vol. 14, no. 9, pp. 61-73, 2019. https://doi.org/10.3991/ijet.v14i09.9535

[48] M. Y. Abdullah, S. Hussin, and M. Shakir, "The Effect of Peers' and Teacher's EFeedback on Writing Anxiety Level Through CMC Applications," Int. J. Emerg. Technol. Learn., vol. 13, no. 11, pp. 196-207, 2018. https://doi.org/10.3991/ijet.v13i11.8448

\section{$7 \quad$ Authors}

Bening Sri Palupi is a postgraduate student in Universitas Sebelas Maret. E-mail: beningsip@student.uns.ac.id.

Slamet Subiyantoro is a professor in Faculty of Teacher Training and Education, Universitas Sebelas Maret.

Triyanto is a doctoral in Civic Education Departement, Universitas Sebelas Maret.

Rukayah is a doctoral in Faculty of Teacher Training and Education, Universitas Sebelas Maret.

Article submitted 2019-08-09. Resubmitted 2019-09-22. Final acceptance 2019-09-22. Final version published as submitted by the authors. 